\title{
CREATIVE PROBLEM SOLVING (CPS)-BASED ASSESSMENT INSTRUMENT FOR CRITICAL THINKING ABILITY ON STOICHIOMETRY MATERIALS
}

\author{
Agustini \\ Universitas Riau, Riau, Indonesia \\ Email: agustinihusniwan@gmail.com \\ R. Usman Rery \\ Universitas Riau, Riau, Indonesia \\ Email: rery1959@gmail.com \\ Lenny Anwar \\ Universitas Riau, Riau, Indonesia \\ Email: lenny_an_war@yahoo.com
}

DOI: 10.35445/alishlah.v12.i2.227

Accepted: August $21^{\text {st }}, 2020$. Approved: November $1^{\text {st }}, 2020$

Published: December $30^{\text {th }}, 2020$

\begin{abstract}
The purpose of this study is to design Creative Problem Solving (CPS)-based assessment instrument for critical thinking ability on stoichiometry materials. The method of development utilized in this study is Research and Development $(R \& D)$ adapted from Borg \& Gall Model which consists of 10 development steps. However, In this study, only up to the third stage, namely the initial product development stage of the assessment instrument for the critical thinking ability of students based on CPS on Stoichiometric material. The main target in the final result of this research is to design a valid CPS-based critical thinking ability assessment instrument on Stoichiometry material that is valid so that it is suitable for use. The assessment instrument developed produced 10 items which were declared valid and reliable with a reliability price of 0.749. The CPS-based critical thinking ability assessment instrument provides more comprehensive information about the characteristics of the instrument that has been developed.
\end{abstract}

Keywords: Assessment Instruments, Critical Thinking, CPS

\section{INSTRUMEN PENILAIAN KEMAMPUAN BERPIKIR KRITIS BERBASIS CREATIVE PROBLEM SOLVING (CPS) PADA MATERI STOIKIOMETRI}

\begin{abstract}
Abstrak
Penelitian ini bertujuan untuk mendesain instrumen penilaian kemampuan berpikir kritis peserta didik berbasis CPS pada materi Stoikiometri. Metode
\end{abstract}


Al-Ishlah: Jurnal Pendidikan - ISSN: 2087-949o (p); 2597-940X (e)

Vol. 12, No. 2 (2020)

pengembangan yang digunakan mengacu pada jenis penelitian Research and Development $(R \& D)$ yang diadaptasi dari Model Borg \& Gall, yang terdiri dari 10 langkah pengembangan. Namun, pada penelitian ini hanya sampai pada tahap yang ke tiga yaitu tahap pengembangan produk awal instrumen asesmen kemampuan berpikir kritis peserta didik berbasis CPS pada materi Stoikiometri. Target utama pada hasil akhir dari penelitian ini adalah membuat desain instrumen penilaian kemampuan berpikir kritis berbasis CPS pada materi Stoikiometri yang valid sehingga layak untuk digunakan. Instrumen penilaian yang dikembangkan menghasilkan 10 butir soal yang dinyatakan valid dan reliabel dengan harga reliabilitas sebesar 0,749. Instrumen penilaian kemampuan berpikir kritis berbasis CPS memberikan informasi yang lebih komprehensif mengenai karakteristik instrumen yang telah dikembangkan.

Kata kunci: Instrumen penilaian, berpikir kritis, CPS

\section{PENDAHULUAN}

Penilaian merupakan serangkaian kegiatan untuk memperoleh, menganalisis dan menafsirkan data mengenai proses dan hasil belajar peserta didik yang dilakukan secara sistematis dan berkesinambungan. Penilaian hasil belajar bertujuan untuk memantau proses dan kemajuan belajar siswa serta meningkatkan efektivitas kegiatan pembelajaran. Kegiatan penilaian dalam pembelajaran dapat dijadikan sebagai dasar untuk memperbaiki proses pembelajaran dan sebaliknya proses pembelajaran dapat dijadikan pijakan dalam melaksanakan penilaian (Agustin, 2018). Penilaian dapat memberikan informasi yang dapat meningkatkan pengetahuan peserta didik dalam pembelajaran dan membantu guru dalam pengajaran (Earl, et al., 2011).

Kegiatan penilaian yang dilakukan oleh guru tidak lepas dari penggunaan instrumen. Instrumen merupakan bagian integral dari suatu proses penilaian dalam pembelajaran, apa yang hendak diukur dalam pembelajaran terkait dengan ketersedia alat ukur yang digunakan (Amalia dan Susilaningsih, 2014). Pencapaian tujuan pembelajaran kimia yang sebenarnya membutuhkan instrumen penilaian yang tidak hanya mencakup hafalan dan pemahaman saja, tetapi juga dibutuhkan penilaian yang melatih keterampilan berpikir siswa (Arifin, 2000).

Kemampuan berpikir kritis sangat penting untuk dimiliki, karena dapat membantu siswa dalam berpikir secara rasional dalam mengatasi permasalahan yang tengah dihadapi dan mencari serta mengembangkan alternatif pemecahan bagi permasalahan tersebut (Alghafri, et al., 2014). Instrumen yang dirancang dengan baik dan sesuai dengan tingkatan kemampuan berpikir dapat meningkatkan daya berpikir kritis siswa.

Berpikir kritis merupakan salah satu kemampuan dari berpikir tingkat tinggi (higher order thinking skills), kemampuan yang harus dimiliki peserta didik dalam menyelesaikan suatu permasalahan (Kartimi dan Liliasari, 2012). Seseorang yang 
Al-Ishlah: Jurnal Pendidikan - ISSN: 2087-9490 (p); 2597-940X (e)

Vol. 12, No. 2 (2020)

mampu berpikir kritis dapat menghasilkan pertanyaan dan masalah yang penting, merumuskan dengan jelas, mengumpulkan dan menilai informasi yang relevan, menggunakan ide-ide yang sifatnya abstrak, berpikir dengan pandangan yang luas dan berkomunikasi secara efektif (Asmawati, dkk., 2018).

Hasil wawancara dengan guru Kimia SMA Negeri di Kabupaten Bengkalis dan analisis soal penilaian harian pada materi Stoikiometri diperoleh informasi bahwa guru belum pernah membuat instrumen asesmen untuk mengukur kemampuan berpikir kritis peserta didik, bentuk penilaian yang digunakan selama ini berupa soal pilihan ganda, isian singkat dan tes essei tertutup. Instrumen penilaian digunakan untuk mengukur ketercapaian indikator pembelajaran tanpa memperhatikan kemampuan berpikir kritis peserta didik dan instrumen penilaian yang digunakan masih mengukur aspek hafalan dan pemahaman saja. Soal yang digunakan guru merupakan hasil adopsi dari berbagai sumber. Soal-soal yang sesuai dengan indikator pembelajaran akan dipakai sebagai instrumen asesmen.

Stoikiometri merupakan materi dasar dalam pembelajaran Kimia yang harus bisa dipahami oleh peserta didik. Peserta didik harus mempunyai kemampuan analisa dan matematika yang baik agar dapat menyelesaikan soal-soal perhitungan dengan benar. Dalam stoikiometri terdapat materi konsep mol yang merupakan materi atau konsep dasar dalam perhitungan kimia sehingga menjadi salah satu materi kimia yang esensial secara umum (Rohmah, 2011). Materi Stoikiometri memuat banyak konsep dasar dan perhitungan matematis, sehingga memerlukan kemampuan berpikir kritis agar kompetensi dasar yang tertuang dalam kurikulum 2013 dapat tercapai dengan baik. Pengembangan indikator pencapaian pembelajaran materi Stoikiometri disesuaikan dengan indikator kemampuan berpikir kritis berbasis CPS sehingga dihasilkan suatu instrumen penilaian yang valid dan dapat mengukur kemampuan berpikir kritis peserta didik.

Model pembelajaran yang dapat digunakan untuk mengatasi kemampuan berpikir kritis peserta didik yang masih rendah adalah dengan menggunakan model pembelajaran Creative Problem Solving (CPS) karena dengan model pembelajaran CPS siswa akan lebih aktif dalam proses pembelajaran dan siswa akan terbiasa dalam menyelesaikan dan mengembangkan pola pikir mereka dalam menghadapi suatu permasalahan. Menurut Totiana dan Redjeki (2013), pembelajaran model CPS mempunyai kelebihan antara lain melatih siswa memahami konsep dengan menyelesaikan masalah, membuat siswa aktif dalam pembelajaran, mengembangkan kemampuan berpikir dan dapat menerapkan pengetahuan yang dimilikinya.

Penelitian pengembangan instrumen penilaian berpikir kritis berbasis CPS diharapkan dapat membantu guru melakukan penilaian mencakup aspek kognitif siswa. Susilo, dkk., (2012) pembelajaran CPS melibatkan aktivitas berpikir tingkat tinggi yang aktif pada siswa terutama berpikir kritis sehingga metode 
Al-Ishlah: Jurnal Pendidikan - ISSN: 2087-9490 (p); 2597-940X (e)

Vol. 12, No. 2 (2020)

pembelajaran ini dapat dimanfaatkan untuk memberdayakan kemampuan berpikir kritis. Disamping itu, dengan model pemecahan masalah peserta didik terlatih untuk mengidentifikasi, menganalisis dan mengevaluasi permasalahan dengan cermat sehingga peserta didik dapat mengembangkan daya nalarnya secara kritis untuk memecahkan masalah yang dihadapi. Surif, dkk., (2014) peserta didik yang menggunakan strategi pemecahan masalah menunjukkan pemahaman konseptual kimia yang lebih baik dan cenderung menggunakan pendekatan konseptual untuk pemecahan masalah.

Penelitian pengembangan instrumen penilaian berpikir kritis berbasis CPS diharapkan dapat membantu guru untuk melakukan penilaian aspek kognitif peserta didik. Beberapa penelitian relevan yang mendukung penelitian pengembangan instrumen asesmen berpikir kritis berbasis CPS pernah dilakukan dan menunjukkan hasil yang baik. Indah Arifianingsih, dkk (2015) dalam penelitiannya menunjukkan bahwa jenis instrumen yang digunakan di sekolah memiliki tingkatan taksonomi kognitif C1 sampai C2 dan terkadang C3. Instrumen penilaian yang dikembangkan adalah tes essai analisis, lembar aktivitas siswa, dan tes problem solving yang berorientasi pada keterampilan berpikir kritis siswa. Instrumen penilaian yang telah dikembangkan dalam penelitian ini dinyatakan valid dan reliable dan berpengaruh positif terhadap hasil belajar kognitif siswa. Jesicha Muryantono Putri Pradana, dkk (2017) juga pernah melakukan penelitian dengan mengembangkan instrumen asesmen yang memiliki karakteristik Inquiry Lab yaitu observasi, manipulasi, generalisasi, verifikasi dan aplikasi, untuk mengukur kemampuan analitis peserta didik dengan indikator membedakan, mengorganisasi dan mendekonstruksi. Instrumen evaluasi berbasis Inquiry Lab dinyatakan efektif untuk mengukur kemampuan berpikir analisis dan dapat digunakan sebagai alat evaluasi di sekolah.

Instrumen penilaian kemampuan berpikir kritis yang dikembangkan pada penelitian ini, mengadopsi aspek-aspek kemampuan berpikir kritis menurut Ennis (2000) dan disesuaikan dengan karakteristik CPS berdasarkan Vidal (2010) dimodifikasi sesuai dengan materi dan model pembelajaran yang diterapkan dalam penelitian. Adapun target utama penelitian ini adalah melakukan pengembangan instrumen asesmen. Dengan pembuatan desain instrumen asesmen berpikir kritis berbasis CPS diharapkan dapat memberi pengaruh positif terhadap kemampuan berpikir kritis peserta didik, guru mampu melakukan penilaian secara menyeluruh mencakup aspek kognitif peserta didik kelas X SMA terutama pada materi Stoikiometri.

\section{METODE PENELITIAN}

Pendekatan penelitian yang digunakan untuk mengembangkan produk instrumen penilaian kemampuan berpikir kritis peserta didik berbasis CPS pada Materi Stoikiometri adalah pengembangan yang mengacu pada jenis penelitian 
Al-Ishlah: Jurnal Pendidikan - ISSN: 2087-9490 (p); 2597-940X (e)

Vol. 12, No. 2 (2020)

Research and Development (R\&D), yang diadaptasi dari Model Borg \& Gall yang terdiri dari 10 langkah pengembangan, yaitu: (1) penelitian pendahuluan dan pengumpulan informasi, (2) perencanaan, (3) pengembangan produk awal, (4) uji coba tahap awal, (5) revisi produk, (6) uji coba lapangan, (7) revisi produk, (8) uji kelayakan, (9) revisi hasil uji kelayakan, dan (10) deseminasi dan hasil sosialisasi produk akhir (Sugiono, 2012). Dalam pelaksanaan penelitian desain instrumen penilaian kemampuan berpikir kritis siswa berbasis CPS pada Materi Stoikiometri, tidak menggunakan semua langkah-langkah yang terdapat pada pengembangan R \& D dari Model Borg \& Gall. Langkah- langkah yang dilakukan hanya penelitian pendahuluan/pengumpulan informasi, perencanaan dan pengembangan produk awal saja, karena penelitian ini bertujuan untuk membuat desain berupa instrumen asesmen pada materi stoikiometri untuk mengukur kemampuan berpikir kritis peserta didik berbasis CPS pada siswa SMA kelas X berbasis CPS.

\section{HASIL DAN PEMBAHASAN}

Hasil penelitian ini meliputi hasil pada tahap research and information, dan tahap planning.

1. Tahap Penelitian Pendahuluan dan Pengumpulan Informasi

Kajian empiris dilakukan dengan mengadakan pra penelitian secara langsung di SMA Negeri 1 Bengkalis, SMA Negeri 2 Bengkalis dan SMA Negeri 2 Bantan dengan metode wawancara dan dokumentasi. Proses pertama yang dilakukan adalah melakukan wawancara terhadap guru dan melakukan analisis terhadap instrumen soal penilaian harian $(\mathrm{PH})$ yang digunakan disekolah. Alat yang digunakan untuk studi pendahuluan diantaranya daftar pertanyaan wawancara untuk guru dan meminta dokumen instrumen penilaian soal-soal PH yang digunakan guru di sekolah. Penelitian dan pengumpulan informasi berupa hasil wawancara dilakukan pada Guru.

Berdasarkan hasil wawancara yang dilakukan di SMA Negeri 1 Bengkalis, SMA Negeri 2 Bengkalis dan SMA Negeri 2 Bantan diperoleh informasi bahwa (a). Guru belum pernah membuat instrumen asesmen untuk mengukur kemampuan berpikir kritis peserta didik padahal disekolah tempat mereka mengajar sudah menerapkan Kurikulum 2013 yang menuntut peserta didik untuk memunculkan kemampuan berpikir kritis dalam proses pembelajaran, (b). Instrumen asesmen yang digunakan ternyata belum semuanya dilengkapi dengan penyusunan kisi-kisi soal dan belum semua guru membuat sendiri soal tes yang diberikan kepada peserta didik, sebagian besar soal diambil dari buku paket/LKS, (c). Jenis instrumen penilaian yang digunakan selama ini hanyalah berupa soal pilihan ganda dengan lima disktakter, isian singkat dan tes esai tertutup khususnya materi Stoikiometri. Instrumen asesmen yang digunakan masih mengukur aspek hafalan dan pemahaman, (d). Perlu dilakukan pengkajian tentang cara agar peserta 
Al-Ishlah: Jurnal Pendidikan - ISSN: 2087-9490 (p); 2597-940X (e)

Vol. 12, No. 2 (2020)

didik semangat dalam proses pembelajaran dan kemampuan berpikir kritis dalam belajar dapat berkembang. Penggunaan metode pembelajaran yang kurang tepat mengakibatkan hasil belajar peserta didik kurang optimal, sehingga diperlukan suatu motode pembelajaran yang dapat menumbuhkan kemampuan berpikir kritis peserta didik berkembang dengan baik.

Selanjutnya, yang dilakukan oleh peneliti adalah melakukan analisis terhadap instrumen penilaian yang digunakan guru. Dokumen instrumen penilaian soal-soal ulangan harian diambil dari beberapa guru kimia yang digunakan pada saat proses pembelajaran. Instrumen penilaian materi stoikiometri digunakan untuk mengukur ketercapaian indikator pembelajaran tanpa memperhatikan kemampuan berpikir kritis peserta didik, dan instrumen asesmen yang digunakan sebagian besar masih mengukur aspek hafalan (C1), pemahaman (C2) dan hitungan singkat (C3). Hal ini berdasarkan tingkat kognitif Bloom, yaitu C1 (mengingat), C2 (memahami), C3 (mengaplikasikan), C4 (menganalisis), C5 (mengevaluasi) dan C6 (mencipta). Adapun hasil analisis soal penilaian harian dari beberapa bentuk soal yang diperoleh dari guru kimia SMA Negeri di Kabupaten Bengkalis diketahui bahwa soal dengan tingkat kognitif $\mathrm{C} 1$ sebanyak $17,4 \%$, C2 sebanyak 37,4\%, C3 sebanyak 40,4\% dan C4 sebanyak 6,02\%. Soalsoal $\mathrm{PH}$ yang digunakan masih banyak yang berada pada tingkat kognitif $\mathrm{C} 2$ dan C3, sedangkan untuk melatih kemampuan berpikir kritis peserta didik seharusnya soal-soal lebih banyak pada tingkat kognitif mulai dari C3 sampai C6. Hal ini sesuai dengan teori, bahwa kemampuan berpikir ktiris termasuk pada kemampuan berpikir tingkat tinggi. Soal yang digunakan guru merupakan hasil adopsi dari berbagai sumber. Soal-soal yang sesuai dengan indikator pembelajaran akan dipakai sebagai instrumen asesmen. Stoikiometri merupakan materi dasar dalam pembelajaran Kimia yang harus bisa dipahami oleh peserta didik. Peserta didik harus mempunyai kemampuan analisa dan matematika yang baik agar dapat menyelesaikan soal-soal perhitungan dengan benar. Dalam stoikiometri terdapat materi konsep mol yang merupakan materi atau konsep dasar dalam perhitungan kimia sehingga menjadi salah satu materi kimia yang esensial secara umum. Materi Stoikiometri memuat banyak konsep dasar dan perhitungan matematis, sehingga memerlukan kemampuan berpikir kritis agar kompetensi dasar yang tertuang dalam kurikulum 2013 dapat tercapai dengan baik. Pengembangan indikator pencapaian pembelajaran materi Stoikiometri disesuaikan dengan indikator kemampuan berpikir kritis sehingga dihasilkan suatu instrumen asesmen yang valid dan dapat mengukur kemampuan berpikir kritis peserta didik.

2. Tahap Perencanaan

Berdasarkan data pada tahap pendahuluan maka perencanaan dalam penelitian ini adalah mendesain instrumen penilaian kognitif untuk mengukur 
Al-Ishlah: Jurnal Pendidikan - ISSN: 2087-949o (p); 2597-94oX (e)

Vol. 12, No. 2 (2020)

kemampuan berpikir kritis siswa berbasis CPS pada materi Stoikiometri. Adapun tahapan perencanaan yang dilakukan adalah sebagai berikut.

a. Merumuskan indikator soal kemampuan berpikir kritis berbasis CPS

Berdasarkan hasil analisis indikator pembelajaran yang telah dirumuskan, maka selanjutnya menyusun butir-butir soal. Instrumen asesmen kemampuan berpikir kritis yang dikembangkan pada penelitian ini, mengadopsi aspek-aspek kemampuan berpikir kritis dan berbasis CPS sesuai dengan langkah-langkah model pembelajaran CPS kemudian dimodifikasi sesuai dengan materi dalam penelitian.

Indikator kemampuan berpikir kritis dikelompokkan menjadi lima kelompok yang diturunkan menjadi dua belas indikator (Ennis, 2000), dan karakteristik CPS yang digunakan pada instrumen asesmen kemampuan berpikir kritis berbasis CPS adalah karakteristik yang sesuai dengan langkah-langkah model pembelajaran CPS menurut Vidal (2010). Indikator kemampuan berpikir kritis dan karakteristik CPS pada tabel 1.

Tabel 1 Indikator Kemampuan Berpikir Kritis dan Karakteristik CPS

\begin{tabular}{ll}
\hline Indikator Berpikir Kritis & Karakteristik CPS \\
\hline $\begin{array}{l}\text { 1. Memfokuskan pertanyaan, } \\
\text { 2. Menganalisis argumen, }\end{array}$ & $\begin{array}{l}\text { 1. Penemuan } \\
\text { masalah secara }\end{array}$ \\
$\begin{array}{ll}\text { 3. Bertanya dan menjawab pertanyaan, } & \text { umum, } \\
\text { 4. Mempertimbangkan apakah sumber referensi dapat } & \text { 2. Penemuan fakta, } \\
\text { dipercaya atau tidak, } & \text { 3. Klarifikasi } \\
\text { masalah, }\end{array}$ \\
$\begin{array}{ll}\text { 5. Mengobservasi dan mempertimbangkan hasil laporan } \\
\text { observasi, }\end{array}$ & $\begin{array}{l}\text { 4. Pengungkapan } \\
\text { pendapatan, }\end{array}$ \\
6. Mendeduksi dan mempertimbangkan hasil dededuksi, & 5. Penemuan solusi \\
7. Menginduksi dan mempertimbangkan hasil induksi, & 6. Implementasi \\
8. Membuat dan menentukan hasil pertimbangan, & \\
9. Mendefinisikan istilah dan mempertimbangkan suatu & \\
definisi, & Vidal (2010) \\
10. Mengidentifikasi asumsi, & \\
11. Menentukan suatu tindakan & \\
12. Berinteraksi dengan orang lain &
\end{tabular}

Ennis (2011)

b. Menyusun kisi-kisi soal

Instrumen penilaian kognitif yang dikembangkan berupa kisi-kisi soal kemampuan berpikir kritis berbasis yang dilengkapi dengan jawaban. Kisi-kisi soal disusun berdasarkan indikator pembelajaran, kompetensi dasar dan indikator berfikir kritis dan indikator soal. Kisi-kisi yang dibuat adalah kisi-kisi soal uraian 
Al-Ishlah: Jurnal Pendidikan - ISSN: 2087-949o (p); 2597-94oX (e)

Vol. 12, No. 2 (2020)

yaitu 10 soal yang mengacu pada pencapaian indikator kemampuan berpikir kritis dan karakteristik model pembelajaran CPS.

c. Membuat Soal Tes Kemampuan Berpikir Kritis Berbasis CPS

Setelah menyusun kisi-kisi soal, tahap perencanaan berikutnya adalah membuat soal tes kemampuan berbasis kritis sesuai dengan karakteristik CPS. Indikator pembelajaran pada instrumen asesmen soal pertama adalah membuktikan hukum-hukum dasar kimia (hukum Lavoisier, hukum Proust, hukum Dalton, hukum Gay Lussac dan hukum Avogadro), dengan ranah kognitif berdasarkan Taksonomi Bloom (C3), sementara indikator soal yang dikembangkan adalah membuktikan hukum Dalton (hukum perbandingan berganda), dimana indikator berpikir kritisnya adalah menginduksi dan mempertimbangkan hasil induksi, dan karakteristik CPS adalah menemukan fakta dan klarifikasi masalah. Butir soal yang dikembangkan dapat dilihat pada uraian berikut :

Nitrogen dan oksigen dapat membentuk 5 macam senyawa. Dalam 0,75 gr senyawa pertama mengandung 0,50 gr nitrogen, senyawa ke dua mengandung $50 \%$ oksigen, dalam 2,5 gr senyawa ke tiga mengandung $60 \%$ oksigen, dalam 1,50 gr senyawa ke empat mengandung 1 gr oksigen serta dalam 1,75 gr senyawa ke lima mengandung 0,5 gram nitrogen. Buktikan bahwa data tersebut menggambarkan hukum perbandingan berganda!

Indikator pembelajaran pada instrumen asesmen soal kedua adalah menentukan massa atom relatif (Ar) dan massa molekul relatif (Mr), dengan ranah kognitif berdasarkan Taksonomi Bloom (C3), sementara indikator soal yang dikembangkan adalah menentukan massa atom relatif (Ar), rumus molekul senyawa dan nama logam, dimana indikator berpikir kritisnya adalah menentukan suatu tindakan, dan karakteristik CPS adalah klarifikasi masalah, menemukan solusi, dan menemukan penyelesaian masalah. Butir soal yang dikembangkan dapat dilihat pada gambar berikut :

Hidroksida adalah suatu ion diatomik yang terdiri dari oksigen dan hidrogen $\left(\mathrm{OH}^{-}\right)$. Senyawa hidroksida dapat terbentuk dari oksida logam dan air dan unsur-unsur golongan alkali tanah dan air. Unsur-unsur golongan alkali tanah antara lain Be (Berilium), Mg (Magnesium), Ca (Calsium), $\mathrm{Sr}$ (Stronsium),

Ba (Barium) dan Ra (Radium). Suatu senyawa hidroksida memiliki massa molekul relatif $=74$, jika logam pembentuk massa tersebut terletak pada golongan II A, ( $\mathrm{Ar} \mathrm{H}=1$ dan $\mathrm{O}=16$ ) maka:

a. Hitung massa atom relatif logam yang membentuk senyawa tersebut!

b. Tuliskan nama logam tersebut!

c. Tentukan rumus molekul senyawa yang terbentuk!

\section{Gambar 1 Butir Soal Nomor 2 yang Dikembangkan}


Al-Ishlah: Jurnal Pendidikan - ISSN: 2087-949o (p); 2597-940X (e)

Vol. 12, No. 2 (2020)

Indikator pembelajaran pada instrumen penilaian soal ketiga adalah menghitung banyaknya zat dalam campuran (persen massa, persen volume, bagian per juta, kemolaran, kemolalan dan fraksi mol), dengan ranah kognitif berdasarkan Taksonomi Bloom (C4), sementara indikator soal yang dikembangkan adalah menyetarakan persamaan reaksi dan menghitung kadar unsur dalam suatu senyawa, dimana indikator berpikir kritisnya adalah bertanya dan menjawab pertanyaan, dan karakteristik CPS adalah menemukan masalah, menemukan solusi, dan menemukan penyelesaian masalah. Butir soal yang dikembangkan dapat dilihat pada uraian berikut :

Tahukah kamu, manfaat logam Magnesium bagi kita? Ternyata, logam Magnesium sangat banyak manfaatnya dalam kehidupan sehari-hari. Misalnya digunakan di dalam pesawat terbang, perkakas listrik, koper, sepeda dan lain-lain. Sebanyak 0,72 gram batuan $\mathrm{MgCO}_{3}$ dilarutkan dalam $\mathrm{HCl}$ pekat berlebih. Kadar Magnesium dalam larutan ini ditentukan dengan cara mengendapkan sebagai Magnesium hidroksida. Bila massa endapan yang diperoleh adalah 0,285 gram ( $\mathrm{Ar} \mathrm{Cl}=35,5 ; \mathrm{Mg}=24)$, Maka hitunglah kadar Magnesium dalam batuan tersebut!

Indikator pembelajaran pada instrumen penilaian soal ke empat adalah menyetarakan persamaan kimia dan menentukan jumlah mol, massa molar, volum molar gas dan jumlah partikel yang terlibat dalam persamaan reaksi kimia, dengan ranah kognitif berdasarkan Taksonomi Bloom (C4), sementara indikator soal yang dikembangkan adalah menyetarakan persamaan reaksi, menghitung \% massa dalam sampel, menghitung massa molekul, menuliskan rumus kimia, dimana indikator berpikir kritisnya adalah Menganalisis argumen, menginduksi dan mempertimbangkan hasil induksi, berinteraksi dengan orang lain, dan karakteristik CPS adalah menemukan fakta, mengungkapkan pendapat, menemukan solusi, dan menemukan penyelesaian masalah. Butir soal yang dikembangkan dapat dilihat pada gambar berikut :

Dua orang siswa melakukan analisis kandungan ion logam dalam suatu garam sulfat yang mengandung air hidrat (belum tentu bilangan bulat). Analisis dilakukan dengan cara menimbang 0,1471 gram sampel garam sulfat, lalu dilarutkan dalam air dan ditambahkan dengan larutan barium klorida berlebih. Endapan yang diperoleh disaring, dicuci dan ditimbang sebanyak 0,2329 gram. Kedua siswa tersebut mengambil kesimpulan yang berbeda : siswa pertama mengatakan garam mengandung titanium (IV) dan siswa ke dua mengatakan garam mengandung ion natrium. 
Al-Ishlah: Jurnal Pendidikan - ISSN: 2087-949o (p); 2597-94oX (e)

Vol. 12, No. 2 (2020)

a. Tuliskan persamaan reaksi larutan garam sulfat dengan barium klorida berlebih dan hitung persen massa sulfat dalam sampel

b. Berdasar \% massa sulfat yang diperoleh, hitung massa molekul garam sulfat menurut masing-masing siswa

c. Tulis rumus kimia garam-garam yang diperoleh dan buktikan dengan perhitungan yang mendukung temuan masing-masing siswa

\section{Gambar 2 Butir Soal Nomor 4 yang Dikembangkan}

Indikator pembelajaran pada instrumen asesmen soal kelima adalah menentukan penggunaan konsep mol dan hubungannya dengan jumlah partikel, massa molar dan volume molar, dengan ranah kognitif berdasarkan Taksonomi Bloom (C4), sementara indikator soal yang dikembangkan adalah menentukan penggunaan konsep mol dan hubungannya dengan jumlah partikel, dimana indikator berpikir kritisnya adalah menganalisis argumen, mempertimbangkan apakah sumber referensi dapat dipercaya atau tidak, mendefinisikan istilah dan mempertimbangkan suatu definisi, berinteraksi dengan orang lain, dan karakteristik CPS adalah mengungkapkan pendapat, menemukan solusi, dan menemukan penyelesaian masalah. Butir soal yang dikembangkan dapat dilihat pada gambar berikut :

Berdasarkan analisis distribusi curah hujan oleh BMKG, hingga pertengahan Januari 2020, 99\% wilayah Zona Musim (ZOM) di Indonesia akan mengalami musim hujan. Saat itu, hujan lebat. Naura dan Luthfi sedang sibuk membahas soal mengenai partikel atom air. Soal berbunyi

sebagai berikut: Dalam sebuah perhitungan, diketahui bahwa satu mol air terdapat $6,022 \times 10^{23}$ molekul $\mathrm{H}_{2} \mathrm{O}$. Jika dalam satu tetes air hujan terdapat $2 \mathrm{~mol}$ air, berapakah jumlah molekul air hujan, jika tertampung sebanyak 10 tetes? Berapa pula jumlah partikel atomnya? Dari hasil perhitungan yang dilakukan oleh Luthfi diperoleh bahwa jumlah molekul air adalah 120,44 x $10^{23}$ molekul dan jumlah partikel atom air adalah $361,32 \times 10^{23}$ partikel. Namun, menurut Naura ini adalah hasil perhitungan yang salah. Karena tidak sesuai dengan hasil yang ia peroleh. Menurut Anda apakah hasil perhitungan yang dilakukan oleh Luthfi benar?

\section{Gambar 3 Butir Soal Nomor 5 yang Dikembangkan}

Indikator pembelajaran pada instrumen asesmen soal ke enam adalah menentukan penggunaan konsep mol dan hubungannya dengan jumlah partikel, massa molar dan volume molar, dengan ranah kognitif berdasarkan Taksonomi Bloom (C3), sementara indikator soal yang dikembangkan adalah menghitung konsentrasi dan partikel air, menunjukkan hubungan antara mol dengan konsentrasi molar, dan jumlah partikel, dimana indikator berpikir kritisnya adalah menganalisis argumen, dan karakteristik CPS adalah klarifikasi masalah, menemukan fakta, menemukan solusi, dan menemukan penyelesaian masalah. Butir soal yang dikembangkan dapat dilihat pada gambar berikut : 
Al-Ishlah: Jurnal Pendidikan - ISSN: 2087-949o (p); 2597-94oX (e)

Vol. 12, No. 2 (2020)

Air merupakan salah satu zat yang paling
bermanfaat dan sangat dibutuhkan oleh semua
makhluk hidup. Setiap hari kita
memanfaatkan air, namun kita tidak
mengetahui berapa jumlah air yang kita
butuhkan. Contoh yang paling sederhana
adalah segelas air yang kita
minum,sebenarnya berapa partikel air yang
sudah kita minum dalam segelas air tersebut. Misalkan Ratna meminum segelas
air penuh dalam wadah 250 mL. Maka,
a. Hitunglah konsentrasi air yang diminum si Ratna apabila massa air adalah
1,8 gram (Ar $\mathrm{H}=1, \mathrm{O}=16$ )!
b. Hitunglah jumlah partikel air yang diminum Ratna berdasar soal A.!
c. Buatlah rumusan yang menunjukkan hubungan antara mol dengan
konsentrasi molar dan jumlah partikel!

Gambar 4 Butir Soal Nomor 6 yang Dikembangkan

Indikator pembelajaran pada instrumen asesmen soal ke tujuh adalah menghubungkan rumus empiris (RE) dengan rumus molekul (RM), dengan ranah kognitif berdasarkan Taksonomi Bloom (C4), sementara indikator soal yang dikembangkan adalah menentukan rumus RE suatu senyawa, dimana indikator berpikir kritisnya adalah menentukan suatu tindakan, dan karakteristik CPS adalah klarifikasi masalah, menemukan solusi, dan menemukan penyelesaian masalah. Butir soal yang dikembangkan dapat dilihat pada gambar berikut :

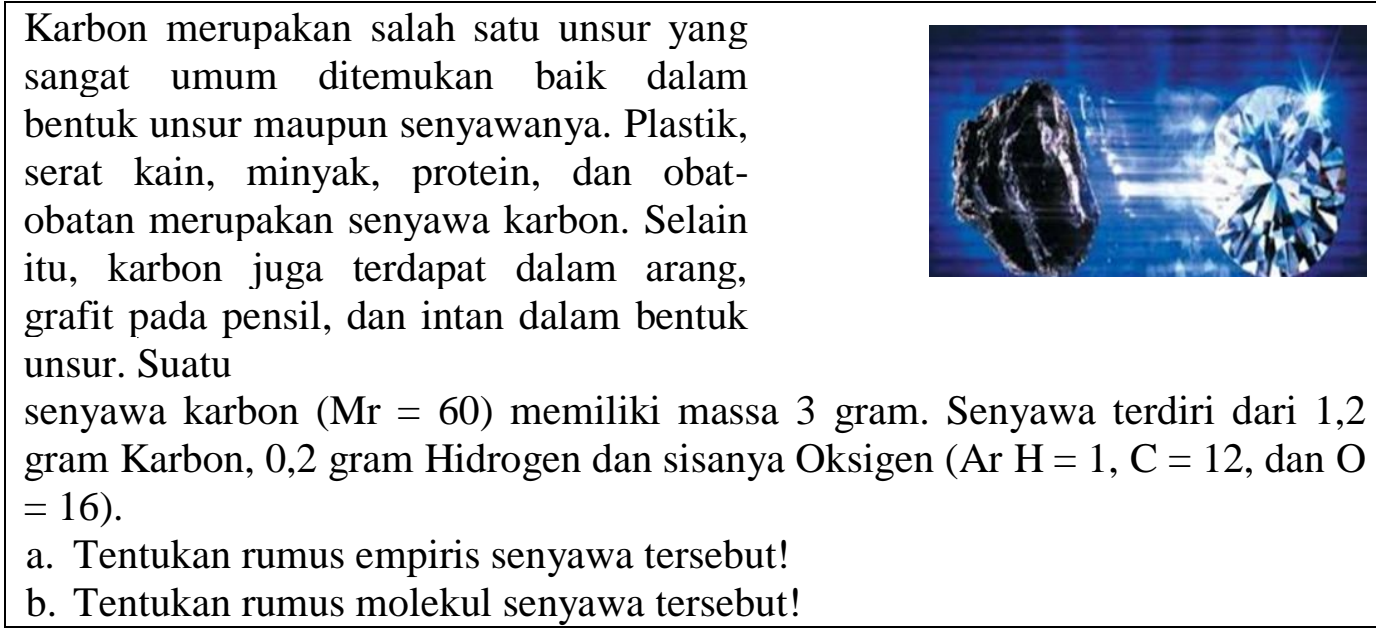

Gambar 5 Butir Soal Nomor 7 yang Dikembangkan

Indikator pembelajaran pada instrumen asesmen soal ke delapan adalah menentukan rumus kimia senyawa hidrat, dengan ranah kognitif berdasarkan Taksonomi Bloom (C3), sementara indikator soal yang dikembangkan adalah menghitung banyaknya molekul air dalam senyawa hidrat, dimana indikator 
Al-Ishlah: Jurnal Pendidikan - ISSN: 2087-949o (p); 2597-94oX (e)

Vol. 12, No. 2 (2020)

berpikir kritisnya adalah menentukan suatu tindakan, dan karakteristik CPS adalah klarifikasi masalah, menemukan solusi, dan menemukan penyelesaian masalah. Butir soal yang dikembangkan dapat dilihat pada gambar berikut :

Senyawa hidrat adalah senyawa yang mengikat air. Contohnya seperti gips $\left(\mathrm{CaSO}_{4} \cdot 2 \mathrm{H}_{2} \mathrm{O}\right)$, digunakan untuk menyambung tulang yang patah. Garam Inggris/garam Epson $\left(\mathrm{MgSO}_{4} \cdot 7 \mathrm{H}_{2} \mathrm{O}\right)$, digunakan untuk obat pencuci perut. Banyak lagi contoh senyawa hidrat lain dalam kehidupan sehari-hari. Jika garam hidrat diuapkan atau melepaskan air kristal, air yang terkandung dalam garam hidrat, yang terikat dinamakan garam anhidrat. Dalam suatu penelitian terdapat suatu garam hidrat $\mathrm{Na}_{2} \mathrm{CO}_{3} \cdot \mathrm{xH}_{2} \mathrm{O}$ yang dipanaskan hingga air kristalnya menguap. Adapun berat senyawa anhidrat sekarang $45,69 \%$ dari berat semula.

a. Berapa nilai air kristal (x)?

b. Prediksi rumus kimia senyawa hidrat?

\section{Gambar 6 Butir Soal Nomor 8 yang Dikembangkan}

Indikator pembelajaran pada instrumen asesmen soal kesembilan adalah menentukan rumus kimia senyawa hidrat, dengan ranah kognitif berdasarkan Taksonomi Bloom (C4), sementara indikator soal yang dikembangkan adalah menentukan rumus dan menghitung massa senyawa hidrat, dimana indikator berpikir kritisnya adalah memfokuskan pertanyaan, menentukan suatu tindakan, dan karakteristik CPS adalah menemukan masalah, menemukan solusi, dan menemukan penyelesaian masalah. Butir soal yang dikembangkan dapat dilihat pada gambar berikut :

$\mathrm{CaSO}_{4}$ diperlukan dalam suatu reaksi di laboratorium, tetapi yang tersedia adalah senyawa hidrat dengan rumus $\mathrm{CaSO}_{4} \cdot \mathrm{xH}_{2} \mathrm{O}$.

a. Sebanyak 67,5 gram senyawa tak dikenal ini dipanaskan hingga semua airnya dilepaskan, menghasilkan 53,4 gram $\mathrm{CaSO}_{4}$ $\left(\mathrm{Mr} \mathrm{CaSO}_{4}=136,2\right)$. Tentukan rumus senyawa hidrat ini dan berapa massa rumusnya?

b. Dengan jumlah senyawa hidrat yang cukup, pemanasan senyawa hidrat menghasilkan 95,5 gram $\mathrm{CaSO}_{4}$. Tentukan berapa gram senyawa hidrat yang harus ditimbang?

\section{Gambar 7 Butir Soal Nomor 9 yang Dikembangkan}

Indikator pembelajaran pada instrumen asesmen soal kesepuluh adalah menentukan pereaksi pembatas dalam persamaan reaksi, dengan ranah kognitif berdasarkan Taksonomi Bloom (C4), sementara indikator soal yang dikembangkan adalah menentukan massa dan $\%$ pereaksi pembatas, dimana 
Al-Ishlah: Jurnal Pendidikan - ISSN: 2087-949o (p); 2597-94oX (e)

Vol. 12, No. 2 (2020)

indikator berpikir kritisnya adalah membuat dan menentukan hasil pertimbangan, menentukan suatu tindakan, dan karakteristik CPS adalah Klarifikasi masalah, Menemukan solusi, dan Menemukan penyelesaian masalah. Butir soal yang dikembangkan dapat dilihat pada gambar berikut :

Titanium adalah logam yang sangat kuat, ringan dan tahan terhadap korosi. Logam ini digunakan sebagai bahan tambahan pada pembuatan roket, mesin jet dan rangka sepeda. Logam Titanium diperoleh dari reaksi antara titanium (IV) klorida dengan magnesium cair pada suhu antara $950^{\circ} \mathrm{C}$ dan $1.150^{\circ} \mathrm{C}$ melalui persamaan kimia sebagai berikut :

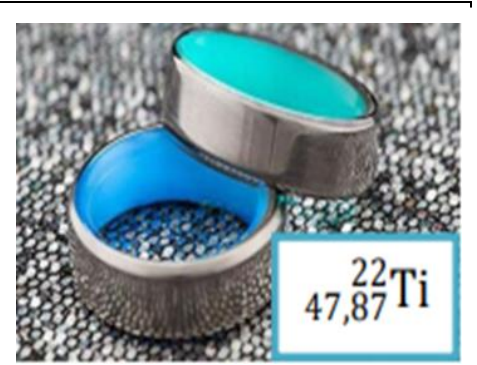

$\mathrm{TiCl}_{4}(\mathrm{~g})+2 \mathrm{Mg}(\mathrm{l}) \rightarrow \mathrm{Ti}(\mathrm{s})+2 \mathrm{MgCl}_{2}(\mathrm{l})$

Dalam suatu kegiatan industri, sebanyak 3,64 x $10^{7}$ gram $\mathrm{TiCl}_{4}$ direaksikan dengan $1,13 \times 10^{7}$ gram $\mathrm{Mg}$.

a. Hitunglah massa teoritis Ti dalam gram

b. Jika ternyata Ti yang didapatkan sebanyak $3,91 \times 10^{6}$ gram, berapa persen hasilnya?

\section{Gambar 8 Butir Soal Nomor 10 yang Dikembangkan}

d. Membuat Rubrik Penskoran dan Penilaian

Kisi-kisi soal yang sudah dibuat kemudian direvisi bersama dosen pembimbing untuk melihat kesesuaian antara soal yang dibuat dengan indikator pembelajaran, indikator soal yang dirumuskan dan indikator kemampuan berpikir kritis berbasis CPS yang diukur. Setelah penyusunan soal tes kemampuan berpikir kritis berbasis CPS selesai, selanjutnya menyusun rubrik penskoran dan penilaian. Soal yang tidak sesuai diganti dengan soal yang baru dan sehingga didapatkan soal yang valid.

\section{Tahap Pengembangan Produk Awal}

Tahap pengembangan produk awal dilakukan bersama dengan teman sejawat pascasarjana sesama peneliti atas bimbingan dosen pembimbing. Pengembangan soal dilakukan bersama dengan teman sejawat karena dengan adanya kerjasama/diskusi bersama dengan teman sejawat dan pembimbing maka ide dan masukan yang diberikan jauh lebih banyak jika dibandingkan pengembangan soalnya dilakukan sendiri. Adapun tahapan yang dilakukan dalam pengembangan produk awal adalah melakukan revisi tujuan pengembangan Instrumen asesmen kemampuan berpikir kritis berbasis CPS pada materi Stoikiometri, melakukan revisi terhadap indikator pembelajaran, melakukan revisi terhadap kisi-kisi soal yang telah dibuat.

Instrumen asesmen dengan soal sebanyak 15 item soal pertanyaan divalidasi isi oleh para ahli menggunakan formula Aiken. Validasi yang dilakukan oleh 
Al-Ishlah: Jurnal Pendidikan - ISSN: 2087-9490 (p); 2597-940X (e)

Vol. 12, No. 2 (2020)

pakar tersebut juga bertujuan untuk melihat apakah alat ukur sudah dapat merepresentasikan topik penelitian yang sudah ditentukan. Setelah validasi, maka dilakukanlah revisi/perbaikan terhadap soal dan kisi-kisi soal sesuai dengan saran atau masukan dari validator dan memberikan hasil revisi kepada validator untuk melakukan validasi kembali. Perbaikan butir soal hasil dari validasi oleh validator yang telah diperoleh digunakan untuk memperbaiki butir-butir soal yang dikembangkan.

Data yang diperoleh dari hasil validasi melalui lembar validasi dianalisis secara deskriptif persentase. Berikut ini nilai validasi isi yang kedua, diperoleh dari 3 orang pakar/validator menggunakan rumus Aiken pada tabel 2.

Tabel 2 Hasil Validasi Isi Menggunakan Rumus Aiken

\begin{tabular}{clcc}
\hline No Soal & Butir Soal & $\begin{array}{c}\text { Indeks Validitas } \\
\text { Aiken }\end{array}$ & Kesimpulan \\
\hline 1 & Soal No. 1 & 0,90 & Valid \\
2 & Soal No. 2 & 0,92 & Valid \\
3 & Soal No. 3 & 0,92 & Valid \\
4 & Soal No. 4 & 0,92 & Valid \\
5 & Soal No. 5 & 0,92 & Valid \\
6 & Soal No. 6 & 0,94 & Valid \\
7 & Soal No. 7 & 0,92 & Valid \\
8 & Soal No. 8 & 0,90 & Valid \\
9 & Soal No. 9 & 0,89 & Valid \\
10 & Soal No. 10 & 0,88 & Valid \\
11 & Soal No. 11 & 0,88 & Valid \\
12 & Soal No. 12 & 0,88 & Valid \\
13 & Soal No. 13 & 0,92 & Valid \\
14 & Soal No. 14 & 0,91 & Valid \\
15 & Soal No. 15 & 0,92 & Valid \\
\hline
\end{tabular}

Berdasarkan Table 2. diperoleh nilai Aiken's (V) berkisar antara 0,88-0,94. Nilai tersebut memenuhi syarat minimal nilai $\mathrm{V}_{\text {tabel }}$ yang diterima yaitu diterima untuk pakar/validator sebanyak 3 orang dengan kategori skala 1-5 pada lembar validasi yaitu bernilai minimal 0,88. Dengan demikian, seluruh butir soal valid sehingga tidak ada soal yang perlu revisi atau dibuang dan soal dapat diuji coba skala terbatas/uji coba lapangan awal. Sedangkan untuk aspek kemampuan berpikir kritis berbasis CPSnya nilai validasinya adalah 95,6\% dengan kategori baik. Dengan demikian instrumen layak untuk digunakan.

\section{SIMPULAN}

Desain pengembangan instrumen asesmen kemampuan berpikir kritis yang dikembangkan pada penelitian ini, mengadopsi aspek-aspek kemampuan berpikir kritis dan karakteristik CPS sesuai dengan langkah-langkah model pembelajaran CPS kemudian dimodifikasi sesuai dengan materi dalam penelitian. 
Al-Ishlah: Jurnal Pendidikan - ISSN: 2087-949o (p); 2597-94oX (e)

Vol. 12, No. 2 (2020)

Pengembangan indikator pencapaian pembelajaran materi Stoikiometri disesuaikan dengan indikator kemampuan berpikir kritis berbasis CPS sehingga dihasilkan suatu instrumen asesmen yang valid dan dapat mengukur kemampuan berpikir kritis peserta didik.

\section{DAFTAR PUSTAKA}

Agustin, N,. Sudarmina,. Sumartia, SS and Addianib, A. K. (2018). Desain Instrumen Tes Bermuatan Etnosains Untuk Mengukur Kemampuan Berpikir Kritis Siswa SMA. Jurnal Inovasi Pendidikan Kimia, 12, 2159-2169.

Alghafri, S.R. dan Hairul N. (2014). The Effects of Integrating Creative and Critical Thinkingon Schools Students' Thinking. International Journal of Social Science and Humanity, 4, 518-525.

Amalia, N.F. dan Susilaningsih, E. (2014). Pengembangan Instrumen Penilaian Keterampilan Berpikir Kritis Siswa SMA Pada Materi Asam Basa. Jurnal Inovasi Pendidikan Kimia, 8, 1380-1389.

Arifin, M. (2000). Strategi Belajar Mengajar Kimia, Prinsip dan Aplikasinya menuju Pembelajaran yang efektif. Bandung: JICA IMSTEP UPI Bandung.

Asmawati, E.Y.S., Rosidin, U. dan Abdurrahman. (2018). Pengembangan Asesmen Kemampuan Berpikir Kritis Peserta Didik pada Pelajaran Fisika SMA dengan Model CPS. Jurnal Pendidikan Fisika, 6, 128-143.

Earl, K.., and Giles, D., 2011, An-other look at Assessment: Assessment in learning, New Zealand Journal of Teachers' work, 8, 11-20.

Ennis, R. H., 2000, At Outline og Goals for a Critical Thingking Curiculum and it assesment, diakses 7 April 2020, from http://criticalthingking.net.

Kartimi dan Liliasari. (2012). Pengembangan Alat Ukur Berpikir Kritis pada Konsep Termokimia untuk Siswa SMA Peringkat Atas dan Menengah. Jurnal Pendidikan IPA Indonesia,1, 21-26.

Rohmah, S. (2011). Pengaruh Problem Solving dalam Meningkatkan Hasil Belajar Kimia Siswa terhadap Konsep Mol dalam Stoikiometri, Unpublished master's thesis, UIN Syarif Hidayatullah at Jakarta.

Sugiyono. (2013). Metode Penelitian Pendidikan Pendekatan Kuantitatif, Kualitatif dan $R \& D$. Bandung: Alfabeta.

Surif, J. Ibrahim, N. dan Dalim, S.F. (2014). Problem Solving Algorithms and Conceptual and Creative Problem Solving in Chemistry, Jurnal Social and Behavior Science, 116, 4955-4963.

Susilo, W., Wiyanto dan Supartono. (2012). Model Pembelajaran IPA Berbasis Masalah untuk Meningkatkan Motivasi Belajar dan Berpikir Kritis Siswa SMP, Unnes Science Educational Jurnal, 1, 12-20.

Totiana dan Redjeki. (2013). Efektivitas Model Pembelajaran Creative Problem Solving (CPS) Yang Dilengkapi Media Pembelajaran Laboratorium Virtual 
Al-Ishlah: Jurnal Pendidikan - ISSN: 2087-949o (p); 2597-94oX (e)

Vol. 12, No. 2 (2020)

Terhadap Prestasi Belajar Siswa Pada Materi Pokok Koloid Kelas XI IPA Semester Genap SMA Negeri 1 Karanganyar Tahun Pelajaran 2011/2012. Jurnal Pendidikan Kimia (JPK), 1, 74-79.

Vidal, R. V. V. (2010). Creative Problem Solving An Applied University Course, Pesquisa Operacional, 30, 405-426. 